\title{
Convention on International Trade in Endangered Species \\ of Wild Fauna and Flora (CITES)
}

\section{Executive Summary}

Carcharodon carcharias (Great White Shark) is a large apical marine predator, widely but sparsely distributed in coastal and offshore shelves in temperate and sub-tropical regions.

- The Great White Shark has a low reproductive rate, reaching sexual maturity at 10-18 years of age and producing between two and ten pups after a 12-18 month gestation period once every two to three years. The species is relatively long-lived, can reach at least 6 metres in length, w eighing over $3000 \mathrm{~kg}$

- The Great White Shark is uncommon compared to other sharks and evidence from its major range states indicates a declining population. Evidence suggests that the population may have declined by at least $20 \%$ over the last three generations, and in some areas the species is considered to have declined even more substantially over the same period.

- In addition to bycatch, the main sources of recorded mortality are sport fishing and the curio trade. The extremely high prices for teeth and jaws in the curio trade stimulate directed take of this species in coastal fisheries. General trade in shark fins has also increased substantially since the 1980s.

- The Great White Shark is classified as globally Vulnerable (VU A $1 c d+2 c d$ ) by the 2000 IUCN Red List, based on its very low reproductive potential and high vulnerability to target and bycatch fisheries, some of which supply extremely high-value products (fins, jaws and teeth) for international trade.

- Since the Great White Shark was included by Australia on Appendix III in 2000, only five (5) Certificates of Origin from trade in the species have been reported to the CITES Secretariat by Parties despite evidence of continuing trade by CITES Parties.

- The Great White Shark meets the criteria listed in Conference Resolution 9.24, Annex 1, Ai \& v, namely that the wild population is small, and is characterised by 'an observed inferred or projected decline in the number of individuals and a high vulnerability due to the species' biology'. The species also meets the criteria in Conference Resolution 9.24 Annex 1, Ci \& ii, namely that 'a decline has been either observed as ongoing or as having occurred in the past, and is inferred and projected on the basis of levels or patterns of exploitation'.

- Australia proposes to include the Great White Shark (Carcharodon carcharias) on Appendix I in accordance with Article II.1. 
AC20 Inf. 23 - p. 2 


\section{A. Proposal}

Inclusion of Carcharodon carcharias (Great White Shark) on Appendix I in accordance with Article II.1 of the Convention on International Trade in Endangered Species of Fauna and Flora. This proposal addresses the relevant criteria of Resolution Conf. 9.24, and emphasises the precautionary measures specified in Annex 4 of the Resolution.

\section{B. Proponent}

\section{Australia}

\section{Supporting Statement}

1. Taxonomy
1.1 Class
1.2 Order
1.3 Family
1.4 Species
1.5 Scientific Synonyms

\subsection{Common Names}

\subsection{Code numbers}

\section{Biological Parameters}

\subsection{Distribution}

The Great White Shark is widely but sparsely distributed throughout temperate and sub-tropical regions in the northern and southern hemispheres. It is primarily found in the coastal and offshore areas of continental and insular shelves and offshore continental islands. The Great White Shark is most abundant near pinniped (Northern Elephant seals or sea-lions) colonies along the Central California Coast, the shelf waters of the mid-Atlantic Bight, the Great Australian Bight, and the Cape and KwaZulu-Natal provinces of South Africa (Fergusson 1996).

\subsection{Habitat Availability}

Great White Sharks appear to move through developmental habitats as they mature. The identification of the Great White Shark habitat is difficult given the unknown nature of their developmental needs at various life stages.

Within its range states, the Great White Shark is often found close to the surf-line and even within shallow bays in continental coastal waters. In waters along the continental shelf, Great White Sharks generally occur near the surface or at the bottom from 16 to 32 metres depth rather than mid water depths (Goldman et al. 1996). Coastal areas are a preferred habitat, and the population level of the 
species could be affected by coastal habitat degradation. The risk of this occurring is heightened as much of the species habitat is in areas with dense human populations.

\subsection{Population Status}

Available data on absolute or total population numbers for the Great White Shark is limited. As large commercial fishing fleets do not target Great White Sharks, information on the volume of catches and landings is poor. What is apparent from research, how ever, is that the Great White Shark is uncommon to rare compared to most sharks. It appears to be very scarce compared to most other widely distributed species and there is considerable evidence from game fishing and beach meshing statistics to demonstrate that the population is in decline.

This decline is reflected in the Great White Shark's globally 'Vulnerable' (Category VU A1cd+ $2 c d$ ) listing on the 2000 IUCN World Conservation Union Red List of Threatened Species (www.redlist.org). This listing recognises that a decline of at least 20 per cent has been observed, inferred or suspected over the last 10 years, or over three generations. The Red List assessment states "The white shark is a widely but sparsely distributed top predator with a very low reproductive potential (late maturity and small litter size) and high vulnerability to target and bycatch fisheries (commercial and recreational), some of which supply products (fins, jaw s and teeth) for international trade. Where detailed population data are available, these indicate that the abundance and average size of white sharks have declined'. The assessment concludes that collation of further data may see its global status revised to Endangered (Fergusson et al., 2003).

Pregnant females are rarely reported, and little is know $\mathrm{n}$ about the reproductive rate and behaviour of the species. Compagno, Marks and Fergusson (1997) reported that the species might have an unusually low fecundity rate for elasmobranches, with both a long gestation period and with relatively few adult females being pregnant at any one time. Great White Shark females do not reproduce before reaching 4.5 - 5.0 metres in length and have a litter of between two to ten pups (Francis, 1996). Males mature at about 3.6 - 3.8 metres. (Bruce, Stevens and Malcolm, 2001). Minimum ages at maturity for females and males are estimated to be 18 and 10 years respectively. The gestation period is unknown but is estimated to exceed 12 months (possibly 18 months) with females breeding only every 2-3 years (Bruce, Stevens and Malcolm, 2001). This is typical of many K-strategists, making them vulnerable to exploitation. ('K-strategist' species are defined has having slow development, relatively large size, and producing only a small number of offspring at a time). Therefore, Great White Shark populations are not adapted to cope with unnatural and sustained declines in population numbers.

Great White Sharks therefore meet the criteria of Conference Resolution 9.24 Annex $1 \mathrm{Ai}$ and v, namely that the wild population is small, and is characterised by 'an observed inferred or projected decline in the number of individuals and a high vulnerability due to the species' biology'.

\subsection{Population and Geographic Trends}

Although there are no quantitative estimates of Great White Shark global population size, numerous trend analyses, local population estimates, and anecdotal data sets indicate global stock declines in recent years. Reliable data comes from a number of sources including beach meshing programs, gamefish captures and catch per unit effort information from commercial captures. A number of studies, and anecdotal evidence in North America, South Africa and Australia, all indicate that numbers are declining. As the studies available have been in Southern Australia, U.S.A. and South Africa - the major range areas of the Great White Shark - they are likely to be indicative of similar trends elsewhere. There is however a scarcity of long term monitoring and studies of populations outside of these areas, and inconsistent methodologies make it difficult to compare data.

Sport fishing data from the east coast of North America and south-eastern Australia, prior to domestic legislation being enacted to protect the Great White Shark indicated declines in the proportions of Great White Sharks taken relative to other shark species caught over the last several decades (Bruce 1992; Casey and Pratt 1985). For example, a study by Pepperell (1992) showed that prior to legislation outlawing sport fishing of the Great White Shark, the number of Great White Sharks relative to other sharks caught by game fishermen off the coast of south-eastern Australia decreased from 1:22 in the 1960 s, to $1: 38$ in the 1970 s to $1: 651$ in the 1980s. This decline in numbers is also reflected in sport fisheries data from the eastern United States, where the proportion of Great White Sharks taken relative to other shark species dropped from 1:67 in 1965 to 1:210 in 1983 (Casey and Pratt 1985). 
In Australia, Great White Sharks are caught in beach meshing apparatus used in New South Wales and Queensland. A total of 498 Great White Sharks have been captured by beach meshing between 1950 and 1996. Captures of Great White Sharks in New South Wales meshes "have shown an almost unbroken decline since the commencement of meshing in 1937" (Reid and Krogh 1992). Catch per unit effort (CPUE) from beach meshing in New South Wales and Queensland has show $\mathrm{n}$ a gradual and irregular decline and there has also been a decrease in average length of Great White Sharks caught in NSW, consistent with a decline in the fishery (Anon, 1996). The average length of Great White Sharks caught between 1950-70 was $2.5 \mathrm{~m}, 2 \mathrm{~m}$ between 1970-90 and down to $1.7 \mathrm{~m}$ in the 1990's (NSW Fisheries, 1997). Declining catch rates in shark nets in Natal, South Africa, have also been reported. A study off the KwaZulu-Natal coast between 1966 and 1993 saw a decline in Great White Shark numbers, with the authors calculating the decline in the latter part of the study, between 1973 and 1993, as significant (Cliff et al. 1996).

Studies indicate that there may be natural fluctuations in Great White Shark abundance in some areas, thought to be related to temperature and (to some extent) life stage. Cliff et al. (1996) noted a cyclical trend of Great White Shark abundance from shark nets along the KwaZulu-Natal coast, peaking at 4 to 6 year intervals. The authors, how ever, do not consider natural fluctuations responsible for the decline over recent decades (Cliff et al. 1996).

Great White Sharks therefore meet the criterion in Annex 1, Ci \& ii, namely that 'a decline has been either observed as ongoing or as having occurred in the past, and is inferred and projected on the basis of levels or patterns of exploitation'.

\subsection{Role of Species in its Ecosystem}

The Great White Shark is an apex predator, and therefore it is presumed to play an important role in the marine ecosystem by, among other things, keeping the population of their prey in check, and aiding the maintenance of genetic fitness of its prey. The diet of smaller Great White Sharks consists mainly of a variety of teleost and elasmobranch fishes, while marine mammals are a major part of the diet for larger sharks (Last and Stevens 1994; Cliff et al. 1996). It is difficult to predict accurately what impact a continued decline of the Great White Shark may have on the ecosystem, "in the absence of more precise information, however, the roles of these fishes should not be underestimated. Indiscriminate removal of apex predators from marine habitats could disastrously upset the balance within the sea's ecosystems" (Last and Stevens 1994: 7).

\subsection{Threats}

The major impacts on Great White Shark populations are largely a result of human actions including

- trade stimulated activities such as

1. intensified targeted commercial fisheries for trophies

2. sports fisheries for trophies

3. direct and incidental fishing pressure

4. incidental catch of the species in commercial and artisanal fisheries

- decline in the abundance of its prey,

- degradation of the shark's habitat,

- protective beach meshing,

The rarity, low reproductivity, and tendency of Great White Sharks to form local populations make it extremely vulnerable to over-exploitation by trade-stimulated fisheries. Evidence suggests they can easily be exploited to the point of extinction, even where relatively few are regularly removed from an environment. For example, research off the Farallon Islands (USA) suggested that the removal of just four Great White Sharks greatly reduced, and possibly eliminated the entire local population of Great White Sharks (Ainley et al. In Cailliet et al. 1985).

Great White Shark teeth and jaws have significant economic value (Compagno et al. 1997). A jaw of a Great White Shark from Gans Bay, recently recovered after being stolen, was valued at US\$50,000. Small jaws may be sold for as much as US $\$ 15,000$, and individual teeth from small sharks for US $\$ 600$ (IUCN Shark Specialist Group 1998). The jaw s from a large pregnant female shark caught recently in New Zealand in November 2003 were put up for auction on the internet, where bidding started at US $\$ 10,000$ (Beston 2003). Direct pressure on Great White Shark populations comes from their being targeted for their teeth, jaws and fins, or when they become a nuisance to fishing operations (Bruce 1992). There is also a commercial market for neonates (Camhi et al. 1998). 
Fishers generally target the larger sharks for their teeth and jaws, which could have a significant impact on population numbers in the long term. The Great White female reaches sexual maturity only when she is approximately 4.5 to 5 metres long, compared to males that reach sexual maturity at 3.5 to 4 metres long, when about twelve or fourteen years old (Camhi et al. 1998). Hence it is the reproductively active females and larger males that are being targeted.

As Great White Shark populations continue to decline, the economic value of trophies such as jaws and teeth will increase, possibly leading to increased targeting, and over-exploitation, as well as grow th of an underground sales netw ork or black market for highly lucrative Great White Shark products (Compagno et al. 1997).

Recent increases in the legal trade of shark fins is reflected in FAO records, where international shark fin imports were recorded at 31 tonnes in 1980, and 335 tonnes in 1990, with the average value of shark fins also increasing over this period (Stoessell 1993). An increased trade in general shark products inevitably increases the incidental catch of the Great White Shark. The Great White Shark is taken as bycatch in fisheries that use longlines, hook-and-line, fixed bottom gillnets, fish traps, herring weirs, and trammelnets, harpoons, and bottom and pelagic trawls, as well as purse seines (Food and Agriculture Organisation of the United Nations 1999). Strong et al. (1996) found through studies in South Australia, that $10 \%$ of Great White Sharks observed were bearing remnants of longlines and gill nets. Bruce (1992) found in the lower Spencer Gulf, South Australia, that 30\% of Great White Sharks sighted had evidence of a previous encounter with commercial fishing gear.

A direct threat to the Great White Shark is from sports fishing. Direct targeting of Great White Sharks, together with developments in fishing equipment and growth in human population and affluence, is likely to have increased its mortality rate in recent decades. While some sports fishers will release alive the Great White Sharks that they target, others travel long distances in order to target this species as a trophy. Such trophies (jaws and teeth) are highly sought after and extremely valuable.

Current population data indicate that it is imperative that the precautionary measures outline in Conference Resolution 9.24 Annex 4, (A), be considered in assessing this proposal. A lack of protective legislation should not preclude effective protection for the Great White Shark, while a lack of local enforcement where protective legislation is in place, and a disregard of protective measures, all form significant threats to shark population numbers (Compagno et al. 1997).

\section{Utilisation and Trade}

\subsection{National Utilisation}

Some of the uses for shark species in general include meat, skins, organs, and tissues for human consumption, carcass used for fish meal and fertiliser, cartilage for medicines, fins for shark-fin soup and even meat of small specimens for fish bait. Great White Sharks have also been used for leather and its liver oil has generalised uses (Rose, 1996). The most prized products of the Great white shark are its teeth and jaws, often sold over the internet to specialised collectors who are prepared to pay in excess of US $\$ 10,000$ for a large, well-preserved jaw, or up to US\$600 for individual teeth.

\subsection{Legal International Trade}

Despite listing under Appendix III of CITES, only five Certificates of Origin for trade in Great White Shark products have been issued, three of which relate to pre-Convention specimens.

It is difficult to ascertain the current level of trade occurring in Great White Shark products. In many cases, shark products are not identified down to species level. There is also a significant amount of misreporting of trade. For example, in 1993, South Africa recorded no export of shark fins to Taiwan, whereas Taiwan records show 3.28 tonnes of shark fin imported from South Africa. The illegal trade in fins contributes to a further underestimate in trade figures. The shark fin market is very competitive, with criminal gangs involved, and a proportion of fins are traded despite being illegal exports (Smale 1996).

Hong Kong fin traders have indicated during some surveys that they prefer Great White Shark fins to those of other species (Lai Ka-Keong 1983), while in Taiw an they are considered of medium grade (Chen 1996). Grading of shark fins depends on their size, thickness and their fin-needle content (Lai Ka-Keong 1983). The quality and quantity of fin needles differ between species, and so do their prices and grades. Higher grades demand higher prices and create a greater incentive to supply. As Hong Kong is an 
important importer, exporter, re-exporter and processor of shark fins, the way they grade Great White Shark fins is significant. The fins are also known to be in trade in Singapore (Rose 1996). Generally, however, Great White Shark fins in trade are not identified, especially in customs coding, and often imports and exports of shark fins are not recorded at all (Rose 1996). In South Korea, Great White Shark meat is reportedly the most valuable meat from shark species, with wholesale prices of US\$7.60 per kilogram for class A meat and US $\$ 3.20$ for class B (Parry-J ones 1996).

\subsection{Illegal Trade}

It is thought that an illegal trade in jaws may exist (Compagno 1996 in Marshall and Barnett 1997), with parts being sourced from nations where they are protected. For example, "It is believed that curio or marine specialty shops throughout the EU sell or import shark products such as teeth and preserved jaws. An avid collector of preserved shark jaws, vertebrae and other body parts has imported these into the UK from North and South America" (Fergusson 1996 in Fleming and Papageorgiou 1997). There are also reports from cage-dive operators in South Africa that some local fishermen are killing Great White Sharks at sea despite the shark's protected status, removing their jaws and fins, and selling them to East Asian flagged longliners (IUCN Shark Specialist Group 1998). Most range states do not regulate the harvest and trade in Great White Shark products.

\subsection{Actual or Potential Trade Impacts}

With a growing trade generally in shark fins, and an extremely high value for Great White Shark trophies, especially for the larger specimens, Great White Sharks are under increasing threat as a direct result of trade.

\subsection{Captive Breeding or Artificial Propagation for Commercial Purposes}

Captive breeding is not a viable option in the near future.

\section{Conservation and Management}

\subsection{Legal Status}

\subsubsection{National}

In Australia, the Great White Shark was listed as vulnerable under the Environmental Protection Biodiversity Conservation Act, 1999, and is fully protected within the Australian Exclusive Economic Zone to 200 nautical miles offshore. Australia has developed a Great White Shark Recovery Plan to minimise the impacts of the key threatening process identified in section 2.6. The Great White Shark is also protected in the State waters of South Australia, Victoria, New South Wales, Tasmania, Queensland and Western Australia.

The Great White Shark is protected in a number of other range states. South Africa established the precedent for domestic protection of Great White Shark, when it prohibited the intentional killing or sale of the species on 11 A pril 1991 (Rose, 1996). Namibia followed South Africa by becoming the second nation to protect the Great White Shark in 1993.

In the United States, the species is protected from direct fishing under various State and national legislation. Further, the 1999 Fishery Management Plan prohibits the landing and sale of Great White Shark throughout its range in US waters of the Atlantic Ocean and adjacent seas (US Fish and Wildlife Service, 1999). Recreational tag and release is still permitted.

Malta protected the Great White Shark in 2000 and is still the only Mediterranean State to have ratified the listing of the species on Appendix II of the Barcelona Convention in 1995.

\subsubsection{International}

In 1996 the World Conservation Union (IUCN) listed the Great White Shark as Vulnerable on its Red List of Threatened Species. This was confirmed on the 2000 Red List. The International Plan of Action on Sharks was produced in 1998 by the FAO but few of its member countries have produced national action plans. Australia currently has a draft National Plan of Action on Sharks. The Great White Shark is currently listed on Appendix III of CITES by Australia, and on Appendix I and II of the Convention on Migratory Species (CMS).

\subsection{Species Management}

\subsubsection{Population Monitoring}

AC20 Inf. 23 - p. 7 
The Australian Commonwealth Scientific and Industrial Research Organisation (CSIRO) is currently studying the migration, biology, and abundance of the Great White Shark. While the majority of this work is occurring in South Australia, studies are extending to other Australian waters. Recent research, based on average annual catch rates, indicates that the current population size of Great White Sharks within Australian waters may lie between 5,500 and 27,000 individuals, markedly lower than the estimated "pristine" or pre-industrial fishing population of between 15,000 - 60,000 (Bruce, Stevens and Malcolm, 2001).

South Africa has informed the Department of the Environment and Heritage (DEH) that there are a number of similar research projects currently underway in parts of Africa that aim to better understand the rate of mortality and population size of the Great White Shark (Natal Sharks Board). There is also detailed research underway on the Californian coast of the USA.

\subsubsection{Management Measures}

The Australian Government has developed a Recovery Plan for the species (under the Environment Protection Biodiversity Conservation Act, 1999), and the CSIRO project mentioned above may also add important information to Great White Shark conservation and management. Some of the management measures recommended in the Recovery Plan for the Great White Shark include:

- monitoring and reducing the impact of commercial fishing on the Great White Shark,

- evaluating the impact of recreational fishing on the Great White Shark

- developing non-lethal shark control alternatives to beach meshing and drumlins

- promoting community education and aw areness in relation to the Great White Shark

- developing a quantitative framew ork to assess the recovery of the Great White Shark

The 1999 U.S shark/tunas/swordfish Fishery Management Plan contains several conservation initiatives for coastal and offshore habitats utilised by Great White Sharks. It includes ways to mitigate the impact of key threatening processes, bans the landing and sale of Great White Shark in the U.S, mandates detailed logbook reports from commercial shark fishermen, and limits Great White Shark sport fishing to catch and release (U.S Fish and Wildlife Service 1999).

In response to the issues highlighted during implementation of the CITES Conference Resolution 9.17, the FAO has prepared an International Plan of Action for the Conservation and Management of Sharks (IPOASHARKS) which was adopted at the $23^{\text {rd }}$ meeting of the FAO Committee on Fisheries (COFI) in 1999. The objective of the IPOA-SHARKS is to ensure the conservation and management of sharks and their long-term sustainable use (FAO Fisheries Department 1999). The plan requires States concerned with the management and conservation status of shark species, to actively identify and report on species-specific biological and trade data on sharks caught in their waters and by their vessels in foreign waters. It also encourages states to adopt, by the COFI meeting in February 2001, a National Plan of Action for the conservation and management of shark stocks (Shark-plan) if sharks are regularly caught in their waters, or by their vessels. In 2001, 116 countries reported having caught shark to the FAO (FAO, 2003a). As reported to the twenty-fifth session of COFI in February 2003, only six countries have developed an NPOA while a further 11 have partially developed an NPOA for sharks (FAO, 2003b).

\subsection{Control Measures}

\subsubsection{International Trade}

The Great White shark is currently listed on Appendix III of CITES by Australia. Appendix III includes all species that any Party identifies as being subject to regulation within its jurisdiction for the purpose of preventing or restricting exploitation, and as needing the cooperation of other Parties in the control of trade. The inclusion of the Great White Shark in Appendix III requires all Parties trading in the species to issue a Certificate of Origin.

Recent information from the CITES Secretariat indicates that only 5 Certificates of Origin for trade in Great White Sharks have been issued since the species' inclusion on Appendix III by Australia in 2000. Given that Australia listed the Great White Shark on Appendix III precisely to increase know ledge on trade volumes and major importing and exporting Parties, and it appears from internet sales (monitoring Ebay) that trade continues at a greater rate, it must be concluded that the Appendix III listing has proven ineffective in delivering data.

It has been argued that fins of the Great White Shark are easily confused with those of other shark species, and processed shark carcasses are equally difficult to identify dow $n$ to species level (Chapman et 
al. 2003). In some cases, products such as shark cartilage pills may consist of a mix of tissues from numerous species, making the task of identifying the presence of Great White Shark even more complex.

Recent advances in forensic DNA technology now enable Great White Shark parts (e.g., dried fins, meat and processed carcasses) to be easily and accurately identified among products from other shark species. Australia is currently investigating the introduction of the genetic test to its border control points to further progress its Great White Shark Recovery Plan, and help meet its obligations under the Convention on Migratory Species, CITES and implement the IPOA-Sharks.

\subsubsection{Domestic Measures}

While there are protective measures in place in Australia, South Africa, US Federal and some state waters, Namibia and Malta, the control measures in place have, in some cases, limited impact, evidenced by the fact that shark teeth and jaws are still freely available from California and South Africa, despite the current trade bans (Fergusson et al. 1996).

\section{Information on Similar Species}

The jaws and teeth of the larger individuals of Great White Shark are distinctive and easily identified by a non-expert. A non-expert can identify the jaws of smaller Great White Sharks, though the fins of smaller individuals of the species may potentially be confused with other coastal shark species. 


\section{Appendices}

\section{A. Range States}

The range states for the Great White Shark are:

Albania, Algeria, Angola, Anguilla, Antigua and Barbuda, Argentina, A ustralia, Bahamas, Barbados, Benin, Bosnia and Herzegovina, Brazil, Cameroon, Canada, Cape Verde, Chile, China, Colombia, Croatia, Cuba, Cyprus, Côte d'Ivoire, Democratic People's Republic of Korea, Dominica, Ecuador, Egypt, Eritrea, Fiji, France (New Caledonia, Guadeloupe, Martinique, Réunion), Gabon, Ghana, Greece, Grenada, Israel, Italy, J apan, J ordan, Kenya, Korea, , Liberia, Libyan Arab J amahiriya, Madagascar, Malta, Marshall Islands, Martinique, Mauritania, Mauritius, Mexico, Monaco, Mozambique, Namibia, New Zealand, Nicaragua, Nigeria, Norfolk Island, Panama, Peru, Philippines, Portugal, Republic of Lebanon, Russian Federation, Saint Kitts and Nevis, Saint Lucia, Saint Vincent and the Grenadines, Saudi Arabia, Senegal, Serbia and Montenegro, Seychelles, Sierra Leone, Slovenia, South Africa, Spain, Sudan, Syrian Arab Republic, The Democratic Republic of the Congo, Togo, Trinidad and Tobago, Tunisia, Turkey, Tuvalu, United Kingdom (Gibraltar, Montserrat), United Republic of Tanzania, United States of America, Uruguay, Viet Nam, Western Sahara, Yemen (IUCN Redlist of Threatened Species 2000). 
Beston. A., (2003). Shark caught in net, now for sale on the internet. New Zealand Herald (NZ) 27 November.

Bruce, B.D. (1992). Preliminary Observations on the Biology of the White Shark, Carcharodon carcharias, in South Australian Waters. Aust. J . Mar. Freshwater Res. 43, 1-11.

Bruce, BD., Stevens, J.D. and Malcolm, H. (2001). Establishing the basis for conservation management of White sharks in Australian waters - Final Report. CSIRO Marine Research, Hobart.

Cailliet, G.M., Natanson, L.J ., Welden, B.A and Ebert, D.A. (1985). Preliminary Studies on the Age and Growth of the White Shark, Carcharodon carcharias, Using Vertebral Bands. Memoirs. 9: 49-60.

Camhi, M. (1998). Sharks on the Line. A Statement By State Analysis of Sharks and Their Fisheries. National Aububon Society, Living Oceans Program. pp158. Islip, New York..

Camhi, M., Fowler, S., Musick, J., Bräutigam, A., and Fordham, S. (1998). Sharks and their relatives. Ecology and Conservation. Occasional Paper 20 of the IUCN Species Survival Commission.

Casey, J.G. and Pratt, H.L.J r. (1985). Distribution of the white shark, Carcharodon carcharias, in the western North Atlantic. South. Calif. Acad. Sci., Mem. 9: 2-14.

Chapman, D.C., Abercrombie, D.L., Douady, C.J ., Pikitch, E.K., Stanhope, M.J . and Shivji, M.S. (2003). A streamlined, bi-organelle, multiplex PCR approach to species identification: Application to global conservation and trade monitoring of the great white shark, Carcharodon carcharias. Conservation Genetics. 4: 415-425. Netherlands.

Chen, H.K. (Ed) (1996). An overview of shark trade in selected countries of Southeast Asia. TRAFFIC Southeast Asia, Petaling J aya. In 'The World Trade in Sharks: A Compendium of TRAFFIC's Regional Studies'. TRAFFIC Network Report.

Cliff, G., Dudley, S.F.J . and J ury M.R. (1996). Catches of White Sharks in KwaZulu-Natal, South Africa and Environmental Influences. In "Great White Sharks: The biology of Carcharodon carcharias" (Klimley, A.P. and Ainley, D.G. Eds.), pp 351-362. Academic Press Inc., California.

Cliff, G., Van Der Elst, R.P., Govender, A., Witthuhn, T.K. and Bullen, E.M. (1996). First Estimates of Mortality and Population Size of White Sharks on the South African Coast. In "Great White Sharks: The biology of Carcharodon carcharias" (Klimley, A.P. and Ainley, D.G. Eds.), pp 393-400. Academic Press Inc.,California.

Compagno, L.J.V., Marks, M.A. and Fergusson, I.K. (1997). Threatened fishes of the world: Carcharodon

carcharias (Linnaeus, 1758) (Lamnidae). Environmental Biology of Fishes 50: 61-62.

Fergusson, I.K. (1996). Distribution and Autecology of the White Shark in the Eastern North Atlantic Ocean and the Mediterranean Sea. In "Great White Sharks: The biology of Carcharodon carcharias" (Klimley, A.P. and Ainley, D.G. Eds.), pp 321-345. Academic Press Inc., California.

Fergusson, I.K., Compagno, L.J.V. and Marks, M.A. (1996). Great White Shark. IUCN Red List of Threatened Species.

Fleming, E.H. and Papageorgiou, P.A. (1997). Shark Fisheries and Trade in Europe. TRAFFIC, Europe.

Food and Agriculture Organization of the United Nations. Carcharodon carcharias (Linnaeus, 1758) (1999).

URL:

http://w w w fao.org/WAICENT/FAOINFO/FISHER Y/sidp/htmls/default. htm . Last updated May 10, 1999.

Food and Agriculture Organization of the United Nations Fisheries Department. The International Plan of Action for the Conservation and Management of Sharks. URL:

http://w w w .fao.org/fi/ipa/manage. asp Last updated March 29, 1999

FAO Fishing Information, Data \& Statistics Unit, (2003a). FISHSTAT Plus. Universal Software for Fishing Statistical Time Series, Version 2.3. FAO, Rome.

FAO, (2003b). Progress in the Implementation of the Code of Conduct for Responsible Fisheries and Related International Plans of Action. Committee on Fisheries, Twenty-fifth Session, 
Rome, Italy, 24 - 28 February 2003. COFI/2003/3Rev.1

Fergusson, I., Compagno, L. \& Marks, M. 2000. Carcharodon carcharias. In: IUCN 2003. 2003 IUCN Red List of Threatened Species. $<w w w$. redlist. org $>$.

Francis, M.P. (1996). Observations on a Pregnant White Shark with a Review of Reproductive Biology. In "Great White Sharks: The biology of Carcharodon carcharias" (Klimley, A.P. and Ainley, D.G. Eds.), pp 157 - 172. Academic Press Inc., California.

Goldman, K.J ., Anderson, S.D., McCosker, J .E., and Klimley, A.P. (1996) Temperature Swimming Depths and Movements of a White Shark at the South Farallon Islands, California. In "Great White Sharks: The biology of Carcharodon carcharias" (Klimley, A.P. and Ainley, D.G. Eds.), pp 111-120. Academic Press Inc., California.

IUCN Shark Specialist Group (1998) Shark New S: New sletter of the IUCN Shark Specialist Group.

http://w w w.flmnh.ufl.edu/fish/organizations/SSG /new sletter.htm . Last updated May 12, 1999.

Lai Ka-keong, E. (1983). Shark fins - processing and marketing in Hong Kong. Infofish Marketing Digest

(5/83): 35-39.

Last, P.R. and Stevens, J.D. (1994). Sharks and Rays of Australia. CSIRO Division of Fisheries.

Marshall, N.T. and Barnett, R. (1997). Trade in Sharks and Shark Products in the Western Indian and Southeast Atlantic. TRAFFIC East/South Africa.

Natal Sharks Board (2000) Summary of research findings on great white sharks. Received through Department of Environmental Affairs and Tourism, Pretoria, South Africa. Prop. 11.48 p. 15
Parry-J ones, R. (1996). TRAFFIC report on shark fisheries and trade in South Korea. In Phipps, M.J. (Comp.). TRAFFIC [East Asia] report on shark fisheries and trade in the East Asian region. TRAFFIC East Asia - Taipei. In 'The World Trade in Sharks: A Compendium of TRAFFIC's Regional Studies'. TRAFFIC Network Report.

Pepperell, J.G. (1992). Trends in the Distribution, Species Composition and Size of Sharks Caught by Gamefish Anglers off Southeastern Australia, 1961-90. Australian J ournal Marine and Freshwater Research. 43, 213-225.

Reid, D.D. and Krogh, M. (1992). Assessment of Catches from Protective Shark Meshing off New South Wales Beaches Between 1950 and 1990. Aust. J ournal Maine and Freshwater Research. 43, 283-296.

Rose, D.A. (1996). An overview of world trade in sharks and other cartilaginous fishes, A TRAFFIC Network Report. TRAFFIC International, Cambridge, United Kingdom.

Smale, M.J. (1996). Trade in shark and shark products in South Africa, In 'The World Trade in Sharks: A Compendium of TRAFFIC's Regional Studies'. TRAFFIC Network Report.

Stoessell, T. (1993). 'Investigation of the International Shark fin Trade'. Unpublished Report, TRAFFIC USA.

Strong, W.R. J r., Nelson, D.R., Bruce, B.D. and Murphy, R.D. (1996). Population Dynamics of White Sharks in Spencer Gulf, South Australia. In "Great White Sharks: The biology of Carcharodon carcharias" (Klimley, A.P. and Ainley, D.G. Eds.), pp 401-414. Academic Press Inc., California.

United States Fish and Wildlife Service response to the draft nomination including information on domestic US protection measures for the species.

$(2000)$ 